\title{
A Systematic Literature Review on Massive Open Online Course for Language Learning
}

\author{
Ghazali Zainuddin', Mohd Shahrul Nizam Danuri², Adnan Mat Ali', Mohammad Imran Ahmad1, \\ Nor Effendy Ahmad Sokri'3, Mohammad Najib Jaffar ${ }^{4}$, Siti Rosilawati Ramlan4, \\ Khairu Barieyah Anshar ${ }^{1}$, Irwan Mahazir Ismail ${ }^{5}$, Harwati Hashim ${ }^{*}$
}

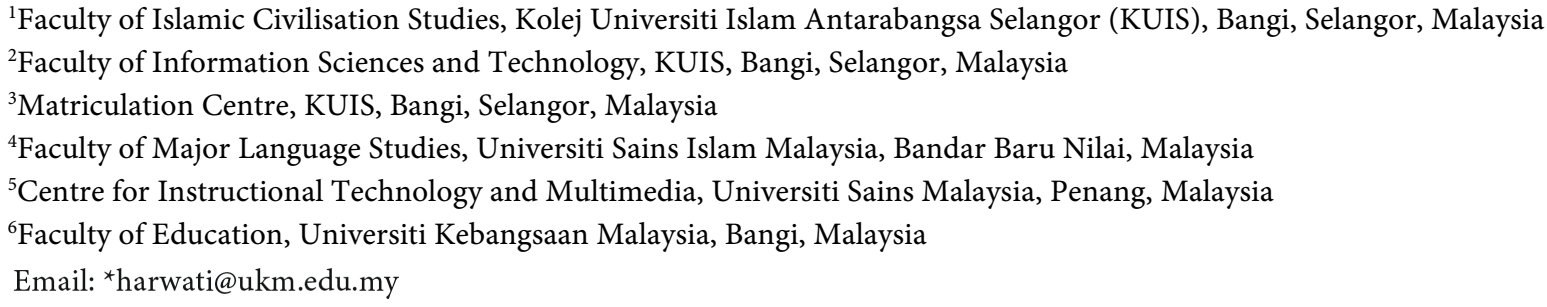

How to cite this paper: Zainuddin, G., Danuri, M. S. N., Ali, A. M., Ahmad, M. I., Sokri, N. E. A., Jaffar, M. N., Ramlan, S. R., Anshar, K. B., Ismail, I. M., \& Hashim, H. (2019). A Systematic Literature Review on Massive Open Online Course for Language Learning. Creative Education, 10, 3195-3204. https://doi.org/10.4236/ce.2019.1012243

Received: October 18, 2019

Accepted: November 27, 2019

Published: November 30, 2019

Copyright (c) 2019 by author(s) and Scientific Research Publishing Inc. This work is licensed under the Creative Commons Attribution International License (CC BY 4.0).

http://creativecommons.org/licenses/by/4.0/

\begin{abstract}
Massive open online course (MOOC) is an online learning tool, especially for distance learning. It has attracted a great deal of attention by higher education institution around the globe. It also gave rise to academic discussion on MOOC impact, design and research. However, researches on MOOC's impact on language learning are still lacking. Therefore, this study aims to assess the research trend in MOOC for language learning around the globe by using the Systematic Literature Review approach from three databases within periods 2013 until 2018. Ten full assessed articles have been selected from ScienceDirect, ERIC and Research gate. The major findings show that the English language has dominated in language learning using MOOC. It is also revealed that MOOC has the potential to enhance language learning among students in other languages.
\end{abstract}

\section{Keywords}

MOOC, Language Learning, Distance Learning, Systematic Literature Review

\section{Introduction}

Nowadays, the Massive Open Online Course (MOOC) has emerged as a powerful platform for distance learning, especially in integrating teaching and learning activities with technology (Fariza Khalid, 2017). Since 2011, there are millions of people from around the world who have used this platform in distance learning 
to enroll in several MOOC providers such as the edX, Cousera and Udacity. The main highlight of participating in MOOC learning is because it is free in several segments (Md. Yusoff et al., 2016; Norman et al., 2015). If charged, it is still reasonable and beyond geographical boundaries and saves time and energy (Sandeen, 2013).

Most Asian MOOC users find these courses as a way to help them gain professional certification (Lim, Wee, Teo, \& Ng, 2017). Additionally, there are several benefits that institutions can gain from offering MOOCs. According to Jansen and Schuwer (2015), European institutions offer MOOCs to attract new students and create flexible learning opportunities. In line with this, many institutions offer MOOC as an opportunity to offer courses including language courses to further enhance their reputations.

Previous research has taken into account several factors in order to consider using MOOCs for learning languages. Firstly, language learning is both knowledge-based and skill-based, in the sense that it needs the combination of vocabularies and grammar and also puts into practice in the form of verbal and non-verbal functional capacities (Halliday, 1993).

Secondly, related to the first point, understanding that the objective of language learning is the use of language itself, it is rational that the learner should practice the language considerably, just like a student must play football to become a footballer or take photographs to become a photographer (Weller, 2014).

Thirdly, Martín-Monje \& Bárcena (2015) added, when all factors above are evenly matched, the mind comes in that learns a language. It is best if the mind is enthusiastic and committed with its high order skills activated. Lastly, one is generally assumed to slowly lose some of the innate language acquisition abilities and acquire a more systematic cognitive form.

Therefore, the process of learning a language will be more effective if it is being done individually partly based on face-to-face, textual, or visual explanations with examples and practice, especially on areas like pronunciation and punctuation.

Some scholars believe that even though MOOC is Open Source Resources also known as Open Online Resources (OER), it is still necessary to conduct a detailed study on its use (Weller, 2014) and future direction (Nordin et al., 2016) in higher learning institutions, especially in language learning. This is confirmed by Martín-Monje \& Bárcena (2015) stating that the use of MOOCs for language learning is still lacking. The existence of MOOCs for language learning has started as early as 2013 but involves learning English only.

\section{Research Objective}

This study attempts to explore the use of MOOCs in learning other languages that may exist to date by emphasizing the pattern and effect of learning on students and teachers. In order to realize how MOOC can significantly contribute 
as an effective pedagogical tool in language learning, a proper investigation of its pattern and effect needs to be carried out. This study also aims to improve the practice of MOOC as a pedagogical tool in language education by investigating trends and its effect on MOOC's effectiveness. This study applied a systematic literature review (see Section 3) in assessing existing MOOC literature. The key contribution of this paper is the findings from the SLR of empirical studies of MOOC in any education settings.

The SLR results integrate evidence into patterns that can be used to understand the current state-of-the-art of research in MOOC when applied to a higher education context. This can better inform educators wanting to incorporate MOOC into a language curriculum. Additionally, conflicting findings from the analysis are presented and gaps in the existing body of knowledge are highlighted. These suggest key areas of focus for future MOOC research. Section III describes the method used in the SLR. Section III reports the results of the SLR based on the synthesis of evidence. Section IV presents a discussion of key findings, implications, threats to the validity of this review, and future work.

\section{The Review Methods}

A SLR is defined as a process of identifying, assessing, and interpreting all available research evidence with the purpose to provide answers for specific research questions (Kitchenham \& Charters, 2007). It is a tool that aims to produce a scientific summary of the evidence in a particular area, in contrast to "traditional" narrative review (Petticrew \& Roberts, 2008). We followed the procedures of Kitchenham et al. (2009).

\subsection{The Procedures}

\subsubsection{Research Questions}

Table 1 shows the PICOC (Population, Intervention, Comparison, Outcomes, and Context) structure of our research questions. In this study included all empirical studies that investigated MOOC within an education setting. Therefore, this study could not include a specific comparison in PICOC. The primary focus of the study was to understand and identify the factors that influence the effectiveness of the MOOC practice for language learning. While the primary reason for using MOOC in industry is to gain benefits in terms of economic advantage (Dybå, Arisholm, Sjøberg, Hannay, \& Shull, 2007) the type of outcomes that

Table 1. Summary of PICOC.

\begin{tabular}{|c|c|}
\hline Population & Educational Institution \\
\hline Intervention & Language learning \\
\hline Comparison & None \\
\hline Outcomes & MOOC's trends \\
\hline Context & $\begin{array}{l}\text { Review(s) of any empirical studies of language learning within the domain of } \\
\text { education. No restrictions on the type of empirical study (e.g. case study) apply. }\end{array}$ \\
\hline
\end{tabular}


can benefit students' learning is what motivates educators (Adzhar et al. 2017; Mcdowell, Werner, Bullock, \& Fernald, 2003): this study organized the measurement of MOOC's effectiveness into four broad categories: academic performance, technical productivity, program or design quality, and satisfaction. Therefore, the SLR aims to answer the following primary research question (RQ):

What evidence is there any MOOC studies conducted in any education settings that investigated MOOC's trends for language learning?

\subsubsection{Identification of Relevant Literature}

The study used strategies to construct the search strings was as follows (Mendes, 2005; Kitchenham et al., 2009):

- Derive major terms used in the review questions (i.e. based on the population, intervention, outcome, and context);

- List the keywords mentioned in the articles (primary studies) that the authors already knew about;

- Search for synonyms and alternative words. This study has also consulted a subject librarian to seek further advice in the proper use of the terms;

- Use the Boolean OR to incorporate alternative spellings and synonyms;

- Use the Boolean AND to link the major terms from population, intervention, and outcome.

The complete search string initially used for the searching of the literature was as follows: (MOOC OR Massive Open Online Course) AND (Language OR Second Language OR Foreign Language) AND (Learning OR teaching) AND (trends OR pattern).

Petticrew and Robert (2008) highlight that the two major issues in conducting SLR search are the sensitivity and specificity of the search. The sensitivity refers to a search that retrieves a high number of relevant studies. Specificity causes the search to retrieve a minimum number of irrelevant studies. In the preliminary search, a very small number of articles had been retrieved when using the complete search string defined above. The keywords "MOOC" OR "language learning" which resulted in a higher number of studies retrieved from various online databases. The primary search process involved the use of 3 online databases: ScienceDirect, ERIC, and Research gate. The authors' experience in literature search supports the suggestion by Kitchenham \& Charters (2007) that it is important for language researchers to identify a list of relevant online databases to facilitate the search process.

Upon completion of the primary search phase, the identification of relevant literature continued with the secondary search phase. During this search phase, all the references in the papers identified from the primary sources were reviewed. If a paper was found to be suitable, it was added to the existing list of studies qualified for the synthesis.

\subsection{Selection of Studies}

The inclusion criteria aimed to only include MOOC empirical studies that tar- 
geted language education and that used MOOC as a practice defined by the XP creators in 1999 (Beck \& Gamma, 2000). As such, the literature search only covered studies published within the period of 2013 to 2018 . The detailed inclusion criteria comprised 1) studies that investigated factors affecting the effectiveness of MOOC for language learning; and 2) studies that measured the effectiveness of MOOC for language learning. The main exclusion criterion comprised MOOC papers not targeted at language learning. In addition the following criteria were also applied: 1) papers presenting claims by the author(s) with no supporting evidence; 2) papers describing development practices other than MOOC, such as test-first programming, refactoring etc; 3) papers that only described tools (i.e. software or hardware) that could support MOOC; 4) papers involving MOOC but solving other disciplines; 5) papers that solely investigated distributed MOOC.

\subsection{Data Extraction and Study Quality Assessment}

To facilitate the data extraction process a form was designed used to gather evidence relating to our research questions and to measure the quality of the primary studies. When designing the studies' quality checklist we reused some of the questions proposed in the literature (Leedy \& Ormrod, 2013; Petticrew \& Roberts, 2008; Fink, 2019; Greenhalgh, 2010). The checklist comprised nine general questions (see Table 2) to measure the quality of both quantitative and qualitative studies according to the following ratio scale: Yes $=1$ point; No $=0$ points; Partially $=0.5$ point. The resulting total quality score for each study ranged between 0 (very poor) and 9 (very good).

One of the authors (Adnan) was responsible for reading and completing the extraction form for each of the primary studies. In order to validate the data extraction process, a random sample comprising $20 \%$ of the total number of primary studies had their data extracted by the first and second authors and then compared in a review meeting. Whenever the data extracted differed, where differences never surpassed more than $10 \%-15 \%$, such differences were discussed until consensus was reached. This study did not measure inter-rater agreement since the review aimed to reach an absolute consensus on the sample used (Brereton, Kitchenham, Budgen, Turner, \& Khalil, 2007). For the remaining 80\% primary studies hopefully the lessons learnt from the review meeting would minimize the bias with their data extraction. If information in a study was unclear, author(s) will be contacted for clarification.

\subsection{Selecting Articles}

After identifying the keyword search (search string), researchers began the process of finding articles in the ScienceDirect database, ERIC and Research gate. The results of the process are described in Table 2.

Below are ten articles that have been selected through this process. The articles are set out in Table 3. 
Table 2. Search results.

\begin{tabular}{cccccccc}
\hline & \multicolumn{7}{c}{ STAGES } \\
\cline { 2 - 8 } SOURCES & A & B & \multicolumn{7}{c}{ C } & D \\
\cline { 2 - 8 } & \multicolumn{7}{c}{ Steps } \\
\cline { 2 - 8 } & $\mathbf{1}$ & $\mathbf{2}$ & $\mathbf{3}$ & $\mathbf{4}$ & $\mathbf{5}$ & $\mathbf{6}$ & $\mathbf{7}$ \\
\hline ScienceDirect & 36 & 10 & 8 & 7 & 3 & 2 & 2 \\
ERIC & 13 & 7 & 7 & 4 & 4 & 4 & 3 \\
Research gate & 17 & 10 & 6 & 6 & 6 & 5 & 5 \\
Total & 66 & 27 & 21 & 17 & 13 & 11 & 10 \\
\hline
\end{tabular}

Table 3. Details of selected articles.

\begin{tabular}{|c|c|c|c|}
\hline ID & Author & Source & Articles' title \\
\hline M1 & $\begin{array}{l}\text { Patricia Ventura, Elena Barcena \& } \\
\text { Elena Martin-Monje (Ventura, } \\
\text { Bárcena, \& Martín-Monje, 2014) }\end{array}$ & ScienceDirect & $\begin{array}{l}\text { Analysis of The Impact Of Social } \\
\text { Feedback on Written production } \\
\text { and Student Engagements in } \\
\text { Language Moocs. }\end{array}$ \\
\hline M2 & $\begin{array}{l}\text { Ruben Chacon-Beltran } \\
\text { (Chacón-Beltrán, 2014) }\end{array}$ & ScienceDirect- & $\begin{array}{l}\text { Massive Online Open Courses and } \\
\text { Language Learning: the Case for a } \\
\text { Beginners' English Course }\end{array}$ \\
\hline M3 & $\begin{array}{l}\text { Erin D. Reilly, Kyle M. Williams, Rose } \\
\text { E. Stafford, Stephanie B. Corliss, Jannet } \\
\text { C. Walkow \& Donna K. Kidwell (Reilly } \\
\text { et al., 2016) }\end{array}$ & ERIC & $\begin{array}{l}\text { Global Times Call for Global } \\
\text { Measures: Investigating } \\
\text { Automated Essay Scoring in } \\
\text { Linguistically-Diverse MOOCs }\end{array}$ \\
\hline M4 & $\begin{array}{l}\text { Airton Zancanaro \& Maria Jose } \\
\text { Carvalho de Souza Domingues } \\
\text { (Zancanaro \& Domingues, 2018) }\end{array}$ & ERIC & $\begin{array}{l}\text { Massive Open Online Courses } \\
\text { (Mooc) For Teaching Portuguese } \\
\text { For Foreigners: A Case Study }\end{array}$ \\
\hline M5 & $\begin{array}{l}\text { Betsy Gilliland, Ai Oyama \& Pamela } \\
\text { Stacey (Gilliland, Oyama, \& Stacey, } \\
\text { 2018) }\end{array}$ & ERIC & $\begin{array}{l}\text { Second Language Writing in a } \\
\text { MOOC: Affordances and Missed } \\
\text { Opportunities }\end{array}$ \\
\hline M6 & $\begin{array}{l}\text { Roxana Marinescu \& Mariana Nicolae } \\
\text { (Marinescu \& Nicolae, 2014) }\end{array}$ & Research Gate & $\begin{array}{l}\text { MOOCs: Challenges and } \\
\text { Opportunities for Romanian } \\
\text { Universities }\end{array}$ \\
\hline M7 & $\begin{array}{l}\text { Steven White, Manuel Leon-urrutia, } \\
\text { Kate Borthwick \& Su White. (White, } \\
\text { Leon Urrutia, Borthwick, \& White, } \\
\text { 2015) }\end{array}$ & Research Gate & $\begin{array}{l}\text { Massive Open Online Course } \\
\text { Mentoring for a Connected } \\
\text { Community of Practice of } \\
\text { Language Teachers }\end{array}$ \\
\hline M8 & $\begin{array}{l}\text { Ana Ibanex Moreno \& John Traxler } \\
\text { (Ibáñez Moreno \& Traxler, 2016) }\end{array}$ & Research Gate & $\begin{array}{l}\text { MALL-Based MOOCs for } \\
\text { Language Teachers: Challenges and } \\
\text { Opportunities }\end{array}$ \\
\hline M9 & $\begin{array}{l}\text { Anastasios A. Economides \& Maria A. } \\
\text { Perifanou (Economides \& Perifanou, } \\
\text { 2018) }\end{array}$ & Research Gate & $\begin{array}{l}\text { Dimensions Of Openness In } \\
\text { MOOCS \& OERS }\end{array}$ \\
\hline M10 & $\begin{array}{l}\text { Nuraihan Mat Daud, Afiza Mohamad } \\
\text { Ali, Nor Shidrah Mat Daud, Jowati } \\
\text { Juhary \& Raihanah M. M (Daud, Ali, } \\
\text { Daud, Juhary, \& Raihanah, 2018) }\end{array}$ & Research Gate & $\begin{array}{l}\text { A MOOC for Literature Integrated } \\
\text { Language Classroom: Pedagogical } \\
\text { Suggestions for the Development } \\
\text { of Higher Order Thinking Skills } \\
\text { (HOTS) }\end{array}$ \\
\hline
\end{tabular}




\section{Finding and Discussion}

Data is taken from articles previously assessed. Researchers focus on MOOC's pattern and effect on language learning. Data are filtered and ten articles are selected from ScienceDirect, ERIC and Research Gate databases. There are two studies done in Spain and the United Kingdom. While one study is done in the United States, Malaysia, Hawaii and Romania. English Language has dominated the usage of MOOCs while Portuguese became the minority language referred to in the M4 study. To date, the MOOC article related to other languages such as Arabic and Malay has yet to be found in this database. Also, qualitative design is the choice of most researchers.

The score for each study is shown in Table 4. Each study has summed up its score points and translated in percentages to facilitate data interpretation. It is placed in the final column of the table (\% Max S). Table 4 shows the percentage rate given to each article based on the Kitchenham and Charters procedures (Kitchenham \& Charters, 2007) and using the article's rating methods that initiated by Azhar, Mendes and Riddle (2012) as below:

Table 4 shows that most studies score between 6 and 9. Therefore, all articles go beyond the $50 \%$ level and are maintained in this systematic review process. M5 articles and M7 articles get the highest score of 9 out of the total score of 9. That is equal to $100 \%$ because they meet the evaluation criteria. Whereas M1 articles and M4 articles got the lowest score of 6 out of 9 equal to $66.7 \%$. Through this step, all 10 articles have gone through a quality assessment process.

\section{Conclusion}

In accordance with the technology explosion, the implementation of MOOC concept in language learning especially among students at all levels of learning and education is strongly encouraged. More after, in this digital era generation, changes and innovation are easily accepted.

Table 4. Score and percentage rates for each article.

\begin{tabular}{cccccccccccc}
\hline ID & Q1 & Q2 & Q3 & Q4 & Q5 & Q6 & Q7 & Q8 & Q9 & Total & \% Max S \\
\hline M1 & 1 & 0.5 & 1 & 0.5 & 1 & 0 & 0 & 1 & 1 & 6 & 66.7 \\
M2 & 1 & 1 & 1 & 1 & 1 & 1 & 0 & 1 & 1 & 8 & 88.9 \\
M3 & 1 & 0.5 & 1 & 1 & 1 & 1 & 1 & 1 & 0.5 & 8 & 88.9 \\
M4 & 0.5 & 0.5 & 1 & 1 & 1 & 0 & 0 & 1 & 1 & 6 & 66.7 \\
M5 & 1 & 1 & 1 & 1 & 1 & 1 & 1 & 1 & 1 & 9 & 100 \\
M6 & 1 & 1 & 1 & 1 & 1 & 0.5 & 0.5 & 1 & 1 & 8 & 88.9 \\
M7 & 1 & 1 & 1 & 1 & 1 & 1 & 1 & 1 & 1 & 9 & 100 \\
M8 & 1 & 1 & 1 & 1 & 1 & 0 & 0 & 1 & 1 & 7 & 77.8 \\
M9 & 1 & 0.5 & 1 & 1 & 1 & 0 & 0 & 1 & 1 & 6.5 & 72.2 \\
M10 & 1 & 1 & 1 & 1 & 1 & 0 & 0 & 1 & 1 & 7 & 77.8 \\
\hline
\end{tabular}


The findings show that the use and research of MOOCs focusing on other languages such as Arabic and Malay are still lacking. Hence, the use of MOOCs in language learning among students, educators and instructors should be enhanced.

This study also found that qualitative study is the main choice of researchers. This study suggests that a quantitative study should be made to see the acceptance of students and teachers towards MOOC and its effectiveness as a learning platform.

It can also see the effectiveness of MOOCs in the pursuit of language learning and teaching process. Language teachers at all levels are encouraged to realize the importance of MOOCs as one of the latest learning tools. The active participation of language teachers in using MOOCs in the learning and teaching process can provide added value to students.

\section{Acknowledgements}

This research is supported by the KUIS Innovation, Research Grant code PP-FPEND-2019 and GPIK 2018 at the Kolej Universiti Islam Antarabangsa Selangor (2018/P/GPIK/GPP-002).

\section{Conflicts of Interest}

The authors declare no conflicts of interest regarding the publication of this paper.

\section{References}

Adzhar, H., Khalid, F., \& Karim, A. A. (2017). Penggunaan Massive Open Online Course (MOOC) Sebagai Kaedah Pembelajaran Baharu. In M. Rosly, N. A. Azali, \& N. A. Jamaluddin (Eds.). Pembelajaran Abad ke-21: Trend Integrasi Teknologi (pp. 179-188). Bangi: Fakulti Pendidikan UKM.

Azhar, D., Mendes, E., \& Riddle, P. (2012). A Systematic Review of Web Resource Estimation. In Proceedings of the 8th International Conference on Predictive Models in Software Engineering (pp. 49-58). New York: ACM.

https://doi.org/10.1145/2365324.2365332

Beck, K., \& Gamma, E. (2000). Extreme Programming Explained: Embrace Change. Boston, MA: Addison-Wesley Professional.

Brereton, P., Kitchenham, B. A., Budgen, D., Turner, M., \& Khalil, M. (2007). Lessons from Applying the Systematic Literature Review Process within the Software Engineering Domain. Journal of Systems and Software, 80, 571-583.

https://doi.org/10.1016/j.jss.2006.07.009

Chacón-Beltrán, R. (2014). Massive Online Open Courses and Language Learning: The Case for a Beginners' English Course. Procedia-Social and Behavioral Sciences, 141, 242-246. https://doi.org/10.1016/j.sbspro.2014.05.042

Daud, N. M., Ali, A. M., Daud, N. S. M., Juhary, J., \& Raihanah, M. M. (2018). A MOOC for Literature Integrated Language Classroom: Pedagogical Suggestions for the Development of Higher Order Thinking Skills (HOTS).

Dybå, T., Arisholm, E., Sjøberg, D. I., Hannay, J. E., \& Shull, F. (2007). Are Two Heads 
Better than One? On the Effectiveness of Pair Programming. IEEE Software, 24, 12-15. https://doi.org/10.1109/MS.2007.158

Economides, A. A., \& Perifanou, M. (2018). Dimensions of Openness in MOOCs and OERs. In IATED EDULEARN, 10th Annual International Conference on Education and New Learning Technologies (pp. 3684-3693). Palma, Spain: IATED.

https://doi.org/10.21125/edulearn.2018.0942

Fink, A. (2019). Conducting Research Literature Reviews: From the Internet to Paper. Thousand Oaks, CA: Sage Publications.

Gilliland, B., Oyama, A., \& Stacey, P. (2018). Second Language Writing in a MOOC: Affordances and Missed Opportunities. TESL-EJ, 22, 25.

Greenhalgh, T. (2010). How to Read a Paper: The Basics of Evidence-Based Medicine. Hoboken, NJ: John Wiley \& Sons.

Halliday, M. A. (1993). Towards a Language-Based Theory of Learning. Linguistics and Education, 5, 93-116. https://doi.org/10.1016/0898-5898(93)90026-7

Ibáñez Moreno, A., \& Traxler, J. (2016). MALL-Based MOOCs for Language Teachers: Challenges and Opportunities. Porta Linguarum Monograph, No. 1, 73-85.

Jansen, D., \& Schuwer, R. (2015). Institutional MOOC Strategies in Europe. Status Report Based on a Mapping Survey Conducted in October-December 2014.

Khalid, F. (2017). Penggunaan Video berasaskan Pendekatan Pembelajaran Mikro dalam Massive Open Online Course (MOOC): Potensi dan Cabaran. In M. M. Awang et al. (Eds.), Prosiding Konvensyen Kebangsaan Sekolah Kluster Kecemerlangan 2017 (pp. 245-252). Bangi: Kementerian Pendidikan Malaysia.

Kitchenham, B., \& Charters, S. (2007). Procedures for Performing Systematic Literature Reviews in Software Engineering. Durham, NC: Keele University \& Durham University.

Kitchenham, B., Pearl Brereton, O., Budgen, D., Turner, M., Bailey, J., \& Linkman, S. (2009). Systematic Literature Reviews in Software Engineering: A Systematic Literature Review. Information and Software Technology, 51, 7-15. https://doi.org/10.1016/j.infsof.2008.09.009

Leedy, P. D., \& Ormrod, J. E. (2013). Practical Research: Planning and Design (10th ed.). London: Pearson Education Limited.

Lim, V., Wee, L., Teo, J., \& Ng, S. (2017). Massive Open and Online Courses and Open Education Resources in Singapore.

Marinescu, R., \& Nicolae, M. (2014). MOOCS. Challenges and Opportunities for Romanian Universities. In The International Scientific Conference E-Learning and Software for Education (Vol. 1, p. 70). Bucharest: Carol I National Defence University.

Martín-Monje, E., \& Bárcena, E. (2015). Language MOOCs: Providing Learning, Transcending Boundaries. Berlin: Walter de Gruyter GmbH \& Co KG. https://doi.org/10.2478/9783110420067

Mcdowell, C., Werner, L., Bullock, H. E., \& Fernald, J. (2003). The Impact of Pair Programming on Student Performance, Perception and Persistence. In 25th International Conference on Software Engineering (pp. 602-607). Piscataway, NJ: IEEE. https://doi.org/10.1109/ICSE.2003.1201243

Mendes, E. (2005). A Systematic Review of Web Engineering Research. In 2005 International Symposium on Empirical Software Engineering (10 p). Piscataway, NJ: IEEE. https://doi.org/10.1109/ISESE.2005.1541857

Nordin, N., Norman, H., Embi, M. A., Mansor, A. Z., \& Idris, F. (2016). Factors for De- 
velopment of Learning Content and Task for MOOCs in an Asian Context. Journal of International Education Studies, 9, 48-61. https://doi.org/10.5539/ies.v9n5p48

Norman, H., Dogan, H., Nordin, N., Mahamod, Z., \& Halim, L. (2015). An Asia-Europe Massive Open Online Course for Lecturer Training: Development of Pedagogical Strategies for MOOCs. In Proceeding of Public University Dean's Council 2015 Seminar (pp. 451-454). Batu Pahat: ACTiVE, UTHM.

Petticrew, M., \& Roberts, H. (2008). Systematic Reviews in the Social Sciences: A Practical Guide. Hoboken, NJ: John Wiley \& Sons.

Reilly, E. D., Williams, K. M., Stafford, R. E., Corliss, S. B., Walkow, J. C., \& Kidwell, D. K. (2016). Global Times Call for Global Measures: Investigating Automated Essay Scoring in Linguistically-Diverse MOOCs. Online Learning, 20, 217-229. https://doi.org/10.24059/olj.v20i2.638

Sandeen, C. (2013). Assessment's Place in the New MOOC World. Research \& Practice in Assessment, 8, 5-12.

Ventura, P., Bárcena, E., \& Martín-Monje, E. (2014). Analysis of the Impact of Social Feedback on Written Production and Student Engagement in Language MOOCs. Procedia-Social and Behavioral Sciences, 141, 512-517.

https://doi.org/10.1016/j.sbspro.2014.05.089

Weller, M. (2014). The Battle for Open. London: Ubiquity Press. https://doi.org/10.5334/bam

White, S., Leon Urrutia, M., Borthwick, K., \& White, S. (2015). Massive Open Online Course Mentoring for a Connected Community of Practice of Language Teachers. E-Learning Papers, 45, 43-48.

Zancanaro, A., \& Domingues, M. J. C. de S. (2018). Massive Open Online Courses (MOOC) for Teaching Portuguese for Foreigners: A Case Study. Turkish Online Journal of Distance Education, 19, 4-20. https://doi.org/10.17718/tojde.415602 